\title{
BIOLOGICAL AND AGRONOMICAL ASSESSMENT OF WHEAT LANDRACES CULTIVATED IN MOUNTAIN AREAS OF UZBEKISTAN
}

\section{S.K. BABOEV'1, A.K. BURANOV', T.A. BOZOROV', B.Sh. ADYLOV1, A.I. MORGUNOV 2 , Kh. MUMINZHONOV 3}

\begin{abstract}
${ }^{1}$ Institute of Plant Genetics and Experimental Biology, Uzbekistan Academy of Sciences, p/o Yukori-yuz, Tashkent Province, Kibraiskii Region, 111226 Republic of Uzbekistan, e-mail sai-baboev@yandex.ru (corresponding author); 2International Maize and Wheat Improvement Center (CIMMYT), P.K. 39 Emek, 06511 Ankara, Turkey, e-mail a.morgounov@cgiar.org;

${ }^{3}$ FAO Subregional Office for Central Asia (FAO SEC), Ivedik Cad. No. 55, 06170 Yenimahalle, Ankara Turkey, e-mail Hafiz.Muminjanov@fao.org

ORCID: Bozorov T.A. orcid.org/0000-0002-8925-6533

The authors declare no conflict of interests
\end{abstract}

Received March 23, 2017

\section{Abstract}

Wheat cultivation for thousands of years under extreme environment of the Central Asia resulted in local wheat cultivars adapted to local soil and climatic conditions. In the past, main wheat production in Uzbekistan was concentrated on dry-farming land of piedmont and mountain regions where precipitation and warm were sufficient as minimal conditions for stable wheat cultivation. Expansion of area under cultivation of intensive high productive commercial wheat cultivars brought decreasing of areas on which wheat landraces had been cultivated. However, wheat landraces were being kept by local farmers in remote districts where no intensive cultivars had been spread widely. Employment of valuable genetic resources of locally originated cultivars is important in plant breeding programs. The aim of current study is to characterize landraces of winter wheat of Uzbekistan by morphological and quality traits (e.g. plant heights, yielding, etc.) with geo-information data on the points of landraces origin, and also to analyze elements of crop productivity. Wheat landraces such as Kzyl-bugday, Ak-bugday, Tyuya-Tish, unnamed landrace and also Surhak (created from local landrace) were used in this study. Landraces differed from commercial cultivars by morphological traits such as plant height, length and density of spike. Selection in the region was carried out by morphological traits. Using GPS-navigation during expedition to survey wheat landraces, a spreading of the studied landraces was mapped. Collected samples of wheat landraces were cultivated during four sessions. Commercial Krasnodarskay 99 served as a control cultivar for comparison. Result of statistical analysis of fifteen lines, i.e. Kzylbugday 2-6T, Kzyl-bugday 3-7T, Kzyl-bugday 9-4T, Kzyl-bugday 5-4T, Kzyl-bugday 11-4T, Kzyl-bugday 1-4T, Ak-bugday 8-2T, Ak-bugday 7-3T, Ak-bugday 16-5T, Surhak 12-3T, Surhak 15-6T, Tyuya-Tish 10-4T, 13-8T (unnamed), 14-3T (unnamed), showed significant difference in plant height compared to the control cultivar. Although the average productivity of studied landraces did not differ from that in the control variety, two landraces, Tyuya-Tish 10-4T and Kzylbugday 1-4T, differed from the control cultivar in productivity. The weight of 1000 kernel was higher in nine landraces, Kzyl-bugday 2-6T, Kzyl-bugday 3-7T, Kzyl-bugday 9-4T, Kzyl-bugday 5-4T, Surhak 12-3T, Kzyl-bugday 1-4T, 14-3T (unnamed), Ak-bugday 16-5T, Surhak 15-6T, compared to the control cultivar. Gluten content was significantly higher in Kzyl-bugday 9-4T, Ak-bugday 8-2T, Ak-bugday 16-5T and 13-8T (unnamed) landraces as compared to Krasnodarskaya 99 cultivar, while medium gluten content was characteristic of other landraces.

Keywords: wheat landraces, morphological analysis, quantitative traits, gluten content

The selection of the majority of agricultural crops faces a serious problem of their extremely sparse genetic diversity. The problem solution is associated with attracting the genetic material of wild relatives and related species $[1,2]$, i.e. overcoming the primary gene pool erosion at the expense of the secondary one included in it. However, the drastic reduction in native habitats of such potential donor species and their polymorphism restriction as a result of keeping insufficiently representative by their composition and small by their size popula- 
tions in gene banks lead to the secondary gene pool loss that limits inevitably the biological diversity expandability for the species cultivated [3-6].

A great number of modern cultivars of wheat (like other crops) are often genetically similar and have a rather limited genetic base [7, 8]. The landraces originated from the natural selection in conjunction with the performance selection carried out by farmers [9-11] have generally wider genetic base that can provide characteristics important for the selection [12]. Such landraces are characterized by their tolerance to local stress factors [13, 14], stable yielding, wider intravariety genetic diversity by protein content and some other grain qualities as compared to existing commercial cultivars [15]. Therefore, they represent a valuable portion of the gene pool $[13,15]$ and shall be involved in breeding new commercial cultivars. Furthermore, traditional varieties-populations not subjected to scientific breeding are of interest for studying plant genetics, physiology and ecology as scientific selection bases [16-18]. Commercial cultivars have completely replaced the traditional landraces in the present-day grain production, therefore, the populations of the latter are of particular value in areas where local landraces are still cultivated, i.e. kept and evolve in natural conditions until the present. In particular, such unique areas include mountain regions of Uzbekistan.

We are the first who has analyzed the distribution of and traits significant for selection in 30 main landraces of wheat gathered in traditionally cultivated areas of mountainous Uzbekistan, and identified samples possessing high baking and taste qualities which are genetically determined and can be introduced to the modern commercial cultivars.

The aim of the study is to describe soft wheat landraces of Uzbekistan by their quantitative and qualitative traits, carry out an analysis of yield components, as well as to show the distribution and crop areas of the landraces, including geoinformation data on cultivated locations.

Technique. The subjects of the study were soft spring wheat landraces such as Kzyl-bugday, Ak-bugday (Graecum), Tyuya-Tish, Pashmak, Khivit, Boboki, Muslimka, Kairaktash, Kzyl-Shark, unnamed landrace, and also Surkhak (bred from a local landrace). Samples were taken during an expedition in 2010 and 2013 in villages (kishlaks) of different districts in three regions.

The samples were cultivated during four seasons (2011-2012, 2012-2013, 2013-2014 and 2014-2015), under irrigation, on the experimental base of the Institute of Genetics and Experimental Biology of Plants of the Academy of Science of Uzbekistan (Tashkent region) in accordance with the described winter wheat cultivation technology [19]. In the first, third and fourth seasons the samples were sown in the III decade of October, while in the second season they were sown in spring. For that, the agricultural practice without vegetative irrigation generally accepted in the study area was used. Ammophos $(200 \mathrm{~kg} / \mathrm{ha})$ was applied to soil before sowing. The samples were sown by hand. Each sample was planted in 3 replicates randomized throughout a $1 \mathrm{~m}^{2}$ plot (with row spacing of $15 \mathrm{~cm}$, row length of $1 \mathrm{~m}$, plot spacing of $30 \mathrm{~cm}$ ). Commercial Krasnodarskaya 99 wheat cultivar was used as a control.

Agronomical estimate and recording of major yield structure components were conducted by conventional methods [20]. Gluten content was determined according to State Standard GOST 13586.1-68 (Grain. Methods for determination of gluten quantity and quality in wheat).

Statistical data analysis was carried out using the Student's $t$-test (StatView 5.0, SAS Institute, Inc., USA) (the analysis did not include data of 20122013 season). Tables contain mean values $(M)$ and significance levels of differences $(\mathrm{p})$. 
Results. Locations of primary cultivation, area planted, and spreading of the studied landraces were identified during the field research using a GPSnavigator (Table 1).

\section{Geographical location and description of traditional wheat landraces sampled}

\begin{tabular}{|c|c|c|c|c|c|}
\hline $\begin{array}{l}\text { Latitude, longitude; } \\
\text { elevation, } \mathrm{m}\end{array}$ & Cultivar & $\begin{array}{l}\text { Sowing } \\
\text { time }\end{array}$ & $\begin{array}{l}\text { Pure line or impurity (\%) and } \\
\text { impurity type in a mixture }\end{array}$ & $\begin{array}{l}\text { Grain } \\
\text { color }\end{array}$ & $\begin{array}{l}\text { Plant } \\
\text { height, cm }\end{array}$ \\
\hline \multicolumn{6}{|c|}{ Yields of 2010} \\
\hline \multicolumn{6}{|c|}{$\begin{array}{c}\text { Surkhandaryinskaya region } \\
\text { Baisunsky District } \\
\text { Duoba Kishlak }\end{array}$} \\
\hline $\begin{array}{l}38^{\circ} 32^{\prime} 121^{\prime \prime} \mathrm{N}, 6^{\circ} 38^{\prime} 181^{\prime \prime} \mathrm{E} \\
1391\end{array}$ & Kzyl-bugday & March & Mixture, $2 \%$, various & Red & 120 \\
\hline $\begin{array}{l}38^{\circ} 32^{\prime} 480^{\prime \prime} \mathrm{N}, 67^{\circ} 36^{\prime} 566^{\prime \prime} \mathrm{E} ; \\
1544\end{array}$ & Boboki & March & Pure line & Red & 120 \\
\hline $\begin{array}{l}38^{\circ} 32^{\prime} 025^{\prime \prime} \mathrm{N}, 67^{\circ} 36^{\prime} 594^{\prime \prime} \mathrm{E} \\
1431\end{array}$ & Kzyl-bugday & March & Pure line & Red & 130 \\
\hline \multicolumn{6}{|c|}{ Kurgancha Kishlak } \\
\hline $\begin{array}{l}38^{\circ} 37^{\prime} 921^{\prime \prime} \mathrm{N}, 67^{\circ} 41^{\prime} 462^{\prime \prime} \mathrm{E} \\
1633\end{array}$ & Kzyl-bugday & March & Mixture, $5 \%$, having red ears & Red & 120 \\
\hline \multicolumn{6}{|c|}{ Gumatak Kishlak } \\
\hline $\begin{array}{l}38^{\circ} 35^{\prime} 699^{\prime \prime} \mathrm{N}, 67^{\circ} 37^{\prime} 737^{\prime \prime} \mathrm{E} ; \\
2136\end{array}$ & Kzyl-bugday & March & Pure line & Red & 130 \\
\hline $\begin{array}{l}38^{\circ} 35^{\prime} 986^{\prime \prime} \mathrm{N}, 6^{\circ} 07^{\prime} 070^{\prime \prime} \mathrm{E} \\
2174\end{array}$ & Kzyl-bugday & March & Mixture, $5 \%$, barley & Red & 130 \\
\hline $\begin{array}{l}38^{\circ} 35^{\prime} 057^{\prime \prime} \mathrm{N}, 67^{\circ} 42^{\prime} 538^{\prime \prime} \mathrm{E} \\
2143\end{array}$ & Kzyl-bugday & March & Pure line & Red & 100 \\
\hline \multicolumn{6}{|c|}{ Pulkhokim Kishlak } \\
\hline $38^{\circ} 16^{\prime} 484^{\prime \prime} \mathrm{N}, 67^{\circ} 38^{\prime} 905^{\prime \prime} \mathrm{E}$ & Boboki & October & Pure line & Red & 140 \\
\hline \multicolumn{6}{|c|}{$\begin{array}{c}\text { Kashkadaryinskaya region } \\
\text { Yakkabagsky District } \\
\text { Guldara Kishlak }\end{array}$} \\
\hline $\begin{array}{l}38^{\circ} 78^{\prime} 582^{\prime \prime} \mathrm{N}, 66^{\circ} 81^{\prime} 014^{\prime \prime} \mathrm{E} \\
1159\end{array}$ & Ak-bugday & March & Pure line & White & 120 \\
\hline $\begin{array}{l}38^{\circ} 77^{\prime} 369^{\prime \prime} \mathrm{N}, 66^{\circ} 82^{\prime} 451^{\prime \prime} \mathrm{E} \\
1270\end{array}$ & Graecum & March & Mixture, $20 \%$, Surkhak landrace & White & 120 \\
\hline \multicolumn{6}{|c|}{ Terakli Kishlak } \\
\hline $\begin{array}{l}38^{\circ} 75^{\prime} 540^{\prime \prime} \mathrm{N}, 66^{\circ} 81^{\prime} 783^{\prime \prime} \mathrm{E} ; \\
1634\end{array}$ & Surkhak & $\begin{array}{l}\text { Novem- } \\
\text { ber }\end{array}$ & Pure line & Red & 130 \\
\hline $\begin{array}{l}38^{\circ} 75^{\prime} 934^{\prime \prime} \mathrm{N}, 66^{\circ} 82^{\prime} 558^{\prime \prime} \mathrm{E} ; \\
1500\end{array}$ & Ak-bugday & $\begin{array}{l}\text { Novem- } \\
\text { ber }\end{array}$ & Pure line & White & 120 \\
\hline \multicolumn{6}{|c|}{$\begin{array}{c}\text { Kamashinsky District } \\
\text { Kuga Kishlak }\end{array}$} \\
\hline $\begin{array}{l}38^{\circ} 66^{\prime} 376^{\prime \prime} \mathrm{N}, 66^{\circ} 92^{\prime} 626^{\prime \prime} \mathrm{E} ; \\
2249\end{array}$ & Ak-bugday & March & Pure line & White & 120 \\
\hline $\begin{array}{l}38^{\circ} 63^{\prime} 243^{\prime \prime} \mathrm{E}, 66^{\circ} 94^{\prime} 461^{\prime \prime} \mathrm{E} \\
1988\end{array}$ & Ak-bugday & March & Pure line & White & 90 \\
\hline $\begin{array}{l}38^{\circ} 64^{\prime} 701^{\prime \prime} \mathrm{N}, 66^{\circ} 93^{\prime} 114^{\prime \prime} \mathrm{E} \\
1731\end{array}$ & Kzyl-bugday & March & Pure line & Red & 120 \\
\hline \multicolumn{6}{|c|}{ Kzyltom Kishlak } \\
\hline $\begin{array}{l}38^{\circ} 61^{\prime} 663^{\prime \prime} \mathrm{N}, 66^{\circ} 93^{\prime} 731^{\prime \prime} \mathrm{E} \\
1753\end{array}$ & Tyuya-Tish & March & Mixture, $15 \%$, having red ears & Red & 120 \\
\hline $\begin{array}{l}38^{\circ} 66^{\prime} 376^{\prime \prime} \mathrm{N}, 66^{\circ} 92^{\prime} 626^{\prime \prime} \mathrm{E} \\
2249\end{array}$ & Unnamed & March & Mixture, $20 \%$, having red ears & Red & 100 \\
\hline $\begin{array}{l}38^{\circ} 65^{\prime} 243^{\prime \prime} \mathrm{N}, 66^{\circ} 90^{\prime} 205^{\prime \prime} \mathrm{E} ; \\
2147\end{array}$ & Unnamed & March & Mixture, $20 \%$, various & Red & 100 \\
\hline $38^{\circ} 59^{\prime} 266^{\prime \prime} \mathrm{N}, 66^{\circ} 91^{\prime} 480^{\prime \prime} \mathrm{E}$; & Ak-bugday & March & Pure line & White & 130 \\
\hline \multicolumn{6}{|c|}{$\begin{array}{c}\text { Dzhizakska y a region } \\
\text { Bakhmalsky District } \\
\text { Muzbulak Kishlak }\end{array}$} \\
\hline $\begin{array}{l}39^{\circ} 71^{\prime} 376^{\prime \prime} \mathrm{N}, 68^{\circ} 12^{\prime} 882^{\prime \prime} \mathrm{E} ; \\
1520\end{array}$ & Ak-bugday & October & Pure line & White & 115 \\
\hline \multicolumn{6}{|c|}{ Zartepa Kishlak } \\
\hline $\begin{array}{l}39^{\circ} 70^{\prime} 017^{\prime \prime} \mathrm{N}, 68^{\circ} 19^{\prime} 329^{\prime \prime} \mathrm{E} ; \\
1763\end{array}$ & Surkhak & March & Mixture, $10 \%$, barley & Red & 120 \\
\hline \multicolumn{6}{|c|}{$\begin{array}{c}\text { Gallyaaralsky District } \\
\text { Yonbosh Kishlak }\end{array}$} \\
\hline $\begin{array}{l}40^{\circ} 12^{\prime} 471^{\prime \prime} \mathrm{N}, 67^{\circ} 41^{\prime} 983^{\prime \prime} \mathrm{E} \\
1449\end{array}$ & Ak-bugday & $\begin{array}{l}\text { Novem- } \\
\text { ber }\end{array}$ & Pure line & White & 130 \\
\hline \multicolumn{6}{|c|}{ Lalmikor Kishlak } \\
\hline $\begin{array}{l}39^{\circ} 93^{\prime} 540^{\prime \prime} \mathrm{N}, 67^{\circ} 45^{\prime} 574^{\prime \prime} \mathrm{E} \text {; } \\
740\end{array}$ & Ak-bugday & $\begin{array}{l}\text { Novem- } \\
\text { ber }\end{array}$ & Mixture, $5 \%$, barley & White & 110 \\
\hline
\end{tabular}


Y i e $1 \mathrm{ds}$ of 2013

Surkhandaryinskaya region

\begin{tabular}{|c|c|c|c|c|}
\hline \multirow[b]{2}{*}{$\begin{array}{l}38^{\circ} 61^{\prime} 500^{\prime \prime} \mathrm{N}, 67^{\circ} 58^{\prime} 411^{\prime \prime} \mathrm{E} \\
2008\end{array}$} & & \multirow[b]{2}{*}{ White } & \multirow[b]{2}{*}{90} \\
\hline & Pashmak & October Pure line & & \\
\hline $\begin{array}{l}38^{\circ} 60^{\prime} 202^{\prime \prime} \mathrm{N}, 67^{\circ} 56^{\prime} 589^{\prime \prime} \mathrm{E} \\
1650\end{array}$ & Khivit & Pure line & White & 90 \\
\hline $\begin{array}{l}38^{\circ} 57^{\prime} 685^{\prime \prime} \mathrm{N}, 67^{\circ} 58^{\prime} 622^{\prime \prime} \mathrm{E} \\
1558\end{array}$ & Kzyl-bugday & Pure line & Red & 110 \\
\hline $\begin{array}{l}38^{\circ} 33^{\prime} 086^{\prime \prime} \mathrm{N}, 67^{\circ} 65^{\prime} 667^{\prime \prime} \mathrm{E} \\
1301\end{array}$ & Graecum & $\begin{array}{l}\text { Altynsaisky District } \\
\text { October Pure line }\end{array}$ & White & 105 \\
\hline $\begin{array}{l}38^{\circ} 31^{\prime} 318^{\prime \prime} \mathrm{N}, 67^{\circ} 04^{\prime} 989^{\prime \prime} \mathrm{N} \\
1289\end{array}$ & Muslimka & $\begin{array}{l}\text { Uzunsky District } \\
\text { October } \text { Mixture, } 20 \% \text {, various }\end{array}$ & Red & 110 \\
\hline $\begin{array}{l}38^{\circ} 58^{\prime} 531^{\prime \prime} \mathrm{N}, 67^{\circ} 57^{\prime} 554^{\prime \prime} \mathrm{E} \\
1615\end{array}$ & Kairaktash & Mixture, $20 \%$, various & White & 100 \\
\hline $\begin{array}{l}38^{\circ} 49^{\prime} 779^{\prime \prime} \mathrm{N}, 67^{\circ} 69^{\prime} 071^{\prime \prime} \mathrm{E} \\
957\end{array}$ & Kzyl-Shark & Mixture, $10 \%$, various & Red & 110 \\
\hline
\end{tabular}

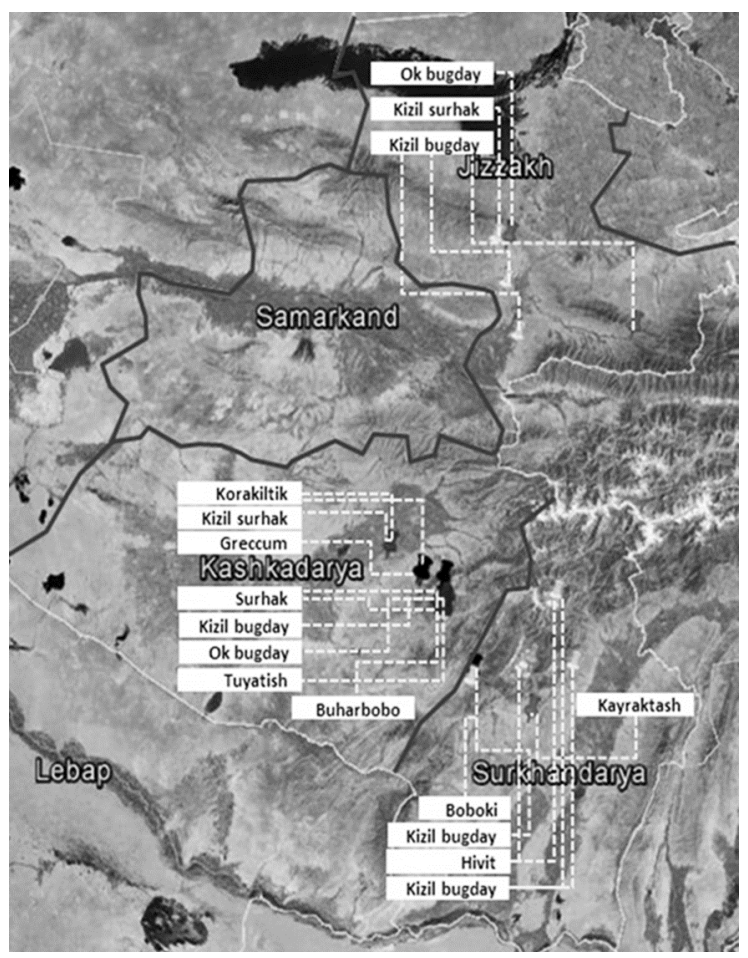

Distribution of traditional spring wheat landraces in $\mathrm{Uz}$ bekistan.

Based on this and numerous polls of the local population, a distribution map of traditional landraces in Uzbekistan has been compiled (see the Figure).

Fifteen lines characterizing the landraces by homogeneity and yields have been selected for 3-year trial plot tests.

In some areas of Uzbekistan where spring wheat is spread, the commercial cultivar Surkhak is grown (it was selected from a traditional landrace in 1940s). The cultivar is relatively resistant to drought, high temperature and shattering (hardly threshed), and nonresistant to lodging. The height of plants is $110-140 \mathrm{~cm}$. Its ear with white glabrous glumes and red grains corresponds to erythrospermum species. It has large kernels (1000 seeds weight up to $50 \mathrm{~g}$ ). The cultivar is characterized by poor winter resistance, but in Uzbekistan lives through winters well. Its vegetation period lasts for 210-240 days. Baking qualities are good, crop yields under optimal conditions reach 3 t/ha. Many crops of the cultivar are extremely unhomogeneous and weedy. Generally, it is grown on large cooperative farms and many neighboring small private farms.

The traditional soft wheat landrace Kzyl-bugday is cultivated on small farms in remote areas at the elevation of 1500-2500 m above sea level. The landrace belongs to erythrospermum variety as well. Its plants are rather high (120$140 \mathrm{~cm}$ ) and highly productive (its yield under optimal conditions reaches $3.5 \mathrm{t} / \mathrm{ha}$ ). It has red, large kernels; the weight of 1000 seeds is $55-60 \mathrm{~g}$. The ears are long, up to $14 \mathrm{~cm}$, with medium awns.

The soft wheat landrace Ak-bugday (known as Graecum in some areas) has white glumes, white awns and relatively large white grain (1000 seeds weight 
45-48 g) that corresponds to characteristics of graecum variety. Its plants are 95$100 \mathrm{~cm}$ high, and do not lodge on bogharic lands. It is grown mainly in two areas (Kashkadaryinskaya and Dzhizakskaya regions). The landrace keeps well, is relatively homogeneous morphologically, and possesses good baking qualities. Its yield reaches up to $3 \mathrm{t} / \mathrm{ha}$. Its straw is very soft, highly respected as a building material for interior finish in houses, as well as is used as fodder for livestock.

The Boboki landrace that is morphologically similar to Kzyl-bugday and referred to erythrospermum variety is grown mainly in mountain areas of southern provinces of Uzbekistan. Its plants are very high $(150-160 \mathrm{~cm})$ with filled stems, they do not lodge in boghara conditions. It is distinguished among traditional landraces by its morphological homogeneity, good quality and high crop yields.

The wheat of Kairaktash landrace (graecum variety) is relatively rare. Its plants are of medium height, resistant to lodging even in irrigation conditions. It possesses excellent baking qualities.

The traditional wheat of Tyuya-Tish landrace is very rare. According to old residents, this landrace was highly productive, had rough grains, possessed good baking qualities, however, it was sown over small areas, primarily, in private households. Currently, it differs from earlier descriptions and corresponds to erythrospermum variety. The landrace plants are high and have large kernels.

Also, there were several unnamed samples (probably, they did not attract attention of peasants or the latter bred the plants they like for their own needs without giving names).

2. Plant stand height and yield in lines of traditional wheat landraces by years of studies (Republic of Uzbekistan)

\begin{tabular}{|c|c|c|c|c|c|c|c|c|c|c|}
\hline \multirow{2}{*}{ Line } & \multicolumn{5}{|c|}{ Plant stand height, $\mathrm{cm}$} & \multicolumn{5}{|c|}{ Yields, $\mathrm{g} / \mathrm{m}^{2}$} \\
\hline & 2012 & 2014 & 2015 & $M$ & $\mathrm{p}$ & 2012 & 2014 & 2015 & $M$ & $\mathrm{p}$ \\
\hline Krasnodarskaya 99 & 70 & 79 & 77 & 75.33 & & 450 & 568 & 655 & 558 & \\
\hline Kzyl-bugday 2-6T & 115 & 124 & 92 & 110.33 & 0.0242 & 432 & 601 & 260 & 431 & 0.3324 \\
\hline Kzyl-bugday 3-7T & 110 & 139 & 100 & 116.33 & 0.0269 & 482 & 673 & 320 & 492 & 0.6059 \\
\hline Kzyl-bugday $9-4 \mathrm{~T}$ & 115 & 113 & 111 & 113.00 & 0.0002 & 400 & 580 & 360 & 447 & 0.2851 \\
\hline Kzyl-bugday 5-4T & 110 & 110 & 107 & 109.00 & 0.0003 & 454 & 576 & 331 & 454 & 0.3232 \\
\hline Kzyl-bugday 11-4T & 115 & 113 & 112 & 113.33 & 0.0002 & 447 & 462 & 250 & 386 & 0.1313 \\
\hline Ak-bugday 7-3T & 90 & 110 & 106 & 102.00 & 0.0163 & 287 & 446 & 370 & 368 & 0.0646 \\
\hline Surkhak 12-3T & 105 & 120 & 106 & 110.33 & 0.0032 & 390 & 538 & 350 & 426 & 0.1855 \\
\hline Ak-bugday 8-2T & 90 & 119 & 105 & 104.67 & 0.0291 & 448 & 426 & 313 & 396 & 0.0896 \\
\hline Tyuya-Tish $10-4 \mathrm{~T}$ & 115 & 130 & 119 & 121.33 & 0.0009 & 388 & 405 & 385 & 393 & 0.0500 \\
\hline Kzyl-bugday 1-4T & 90 & 126 & 115 & 110.33 & 0.0334 & 421 & 325 & 310 & 352 & 0.0404 \\
\hline 13-8T (unnamed) & 110 & 116 & 107 & 111.00 & 0.0007 & 272 & 492 & 432 & 399 & 0.1470 \\
\hline 14-3T (unnamed) & 117 & 129 & 115 & 120.33 & 0.0009 & 440 & 417 & 458 & 438 & 0.1202 \\
\hline Ak-bugday 16-5T & 105 & 104 & 105 & 104.67 & 0.0004 & 417 & 416 & 471 & 435 & 0.1188 \\
\hline Surkhak 15-6T & 110 & 118 & 110 & 112.67 & 0.0006 & 391 & 440 & 385 & 405 & 0.0696 \\
\hline
\end{tabular}

Results of the statistical analysis (Table 2) showed significant difference of all studied 15 lines of traditional wheat landraces from the control cultivar in the plant height, and all the lines were relatively tall-growing. The average yield analysis has shown that in the traditional landraces it was lesser as compared to the control cultivar (Krasnodarskaya 99 cultivar). However, it should be noted that the differences were insignificant, and two lines only (Tyuya-Tish 10-4T and Kzyl-bugday 1-4T) had statistically significant differences from the control cultivar.

The traditional wheat landraces can show high productivity depending on the conditions observed in the relevant year and cultivated location. So, the Kzyl-bugday 3-7T yield in 2014 reached $673 \mathrm{~g} / \mathrm{m}^{2}$ that exceeded the maximum yield of Krasnodarskaya 99 cultivar $\left(655 \mathrm{~g} / \mathrm{m}^{2}\right)$ for the period of 2012 through 2015. It should be noted that deep spring frosts in 2015 caused considerable decrease in the yield of the most traditional landraces, while the Krasnodarskaya 
99 plants were not affected negatively by them. Since the commercial Krasnodarskaya 99 cultivar is characterized by the high yield stability, its average yields have exceeded that of the traditional wheat landraces.

Based on the comparison of the weight of 1000 seeds, it was found out that in nine lines it was higher than in the control cultivar, but the differences were not significant (Table 3). All the lines of traditional landraces had a high content of gluten. It should also be noted that Kzyl-bugday 9-4T, Ak-bugday 8-2T, Ak-bugday 16-5T and 13-8T (unnamed) lines differed significantly from the control cultivar in this trait (see Table 3). All the traditional wheat landraces grown in the mountain and piedmont areas of Uzbekistan were characterized not only by the relatively high content of gluten, but also good baking properties and great taste qualities as compared to the commercial cultivars grown in Uzbekistan. That is one of the reasons why the traditional landraces have been kept and cultivated in the areas concerned for many years.

3. Weight of $\mathbf{1 0 0 0}$ seeds and gluten content in lines of the traditional wheat landraces by years of studies (Republic of Uzbekistan)

\begin{tabular}{l|c|c|c|c|c|c|c|c|c}
\hline \multirow{2}{*}{ Line } & \multicolumn{5}{c|}{ Weight of 1000 seeds, g } & \multicolumn{4}{c}{ Gluten content, \% } \\
\cline { 2 - 10 } & 2012 & 2014 & 2015 & $M$ & $\mathrm{p}$ & 2012 & 2014 & $M$ & $\mathrm{p}$ \\
\hline Krasnodarskaya 99 & 38.0 & 51.0 & 37.0 & 42.00 & & 30.5 & 29.2 & 29.85 & \\
Kzyl-bugday 2-6T & 52.0 & 42.7 & 35.0 & 43.23 & 0.8623 & 33.5 & 34.2 & 33.85 & 0.0324 \\
Kzyl-bugday 3-7T & 52.0 & 43.0 & 37.5 & 44.17 & 0.7436 & 35.1 & 29.2 & 32.15 & 0.5259 \\
Kzyl-bugday 9-4T & 54.0 & 37.0 & 42.0 & 44.33 & 0.7476 & 35.0 & 33.5 & 34.25 & 0.0473 \\
Kzyl-bugday 5-4T & 54.0 & 42.5 & 45.0 & 47.17 & 0.4162 & 22.0 & 35.6 & 28.80 & 0.8919 \\
Kzyl-bugday 11-4T & 50.0 & 37.0 & 40.5 & 42.50 & 0.9371 & 34.5 & 29.8 & 32.15 & 0.4451 \\
Ak-bugday 7-3T & 44.0 & 30.0 & 43.0 & 39.00 & 0.6625 & 32.0 & 28.0 & 30.00 & 0.9496 \\
Surkhak 12-3T & 48.0 & 43.0 & 40.0 & 43.67 & 0.7592 & 28.0 & 26.0 & 27.00 & 0.1394 \\
Ak-bugday 8-2T & 48.0 & 39.0 & 38.5 & 41.83 & 0.9771 & 37.5 & 36.4 & 36.95 & 0.0141 \\
Tyuya-Tish 10-4T & 48.0 & 37.0 & 37.5 & 40.83 & 0.8494 & 32.0 & 31.6 & 31.80 & 0.1032 \\
Kzyl-bugday 1-4T & 50.0 & 37.0 & 42.0 & 43.00 & 0.8734 & 29.0 & 32.0 & 30.50 & 0.7293 \\
13-8T (unnamed) & 42.0 & 40.5 & 39.0 & 40.50 & 0.3267 & 40.5 & 39.6 & 40.05 & 0.0060 \\
14-3T (unnamed) & 52.0 & 35.0 & 44.5 & 43.83 & 0.7971 & 35.0 & 32.4 & 33.70 & 0.1179 \\
Ak-bugday 16-5T & 48.0 & 44.5 & 44.0 & 45.50 & 0.4962 & 35.0 & 36.0 & 35.50 & 0.0204 \\
Surkhak 15-6T & 48.0 & 47.3 & 43.0 & 46.10 & 0.4387 & 35.5 & 29.6 & 32.55 & 0.4657 \\
N o t e. $M-$ arithmetical mean, p - significance level by the Student's $t$-test. & & & \\
\hline
\end{tabular}

The data obtained show that some of the traditional Uzbek wheat landraces have a high potential productivity and elevated gluten content, though they are exceeded by the commercial Krasnodarskaya 99 cultivar in the yield stability. Since the natural productivity is implemented during a critical period from VI to IX organogenesis stages (beginning of stem elongation-end of blooming), in the traditional landraces it may be additionally stimulated by agrochemical exposures, for example, growth regulators (retardants) to be applied during the critical period [21], as well as by genetic selection methods.

Thus, the traditional landraces of Uzbekistan have many traits useful for selection. The collection and study of these landraces are of great importance for preserving the wheat gene pool in the natural conditions. Among them, there are landraces possessing high baking and taste qualities. The traits are genetically determined that makes it possible to use the traditional landraces as donors of high-quality genes in the selection process. The highest weights of 1000 seeds and gluten contents have been found in Kzyl-bugday 2-6T, Kzyl-bugday 3-7T, Kzyl-bugday 9-4T, Kzyl-bugday 11-4T, Ak-bugday 16-5T, Surkhak 15-6T and 14-3T (unnamed) samples.

\section{REFERENCES}

1. Feld ma n M., Kis lev M. Domestication of emmer wheat and evolution of free-threshing 
tetraploid wheat. Isr. J. Plant Sci., 2007, 55: 207-221.

2. D v o rak J., L o u M.-C., Y ang Z-L. Genetic evidence of the origin of Triticum aestivum L. Proc. Harlan Symp. «The origins of agriculture and crop domestication» (10-14 May, 1997, Aleppo, Syria). A.B. Damania, J. Valkoun, G. Wlcox, C.O. Qualset (eds.). ICARDA, IPGRI, FAO, UC/GRCP, 1998: 253-251.

3. Ke lle r L., S c h mid J.E., Ke 11 e r E.R. Are cereal landraces a source for breeding? Landwirtschaft Schweiz, 1991, 4: 197-202.

4. Goncharov N.P., Shumny V.K. Vestnik VOGiS, 2008, 12(4): 509-522. Available http://elibrary.ru/item.asp?id $=12515841$. No date (in Russ.).

5. $\mathrm{B}$ a b o e v S., M o r g o u $\mathrm{n}$ o v A., $\mathrm{M} \mathrm{u} \mathrm{m} \mathrm{i} \mathrm{j}$ a $\mathrm{n} \mathrm{o} \mathrm{v} \mathrm{H}$. Wheat landraces in farmers' fields in Uzbekistan: national survey, collection, and conservation. FAO, Ankara, 2015. Available http://www.fao.org/3/a-i5189e.pdf. No date.

6. F o r d - L i o y d B., J a c k s o n M. Plant genetic resources: an introduction to their conservation and use. Edward Arnold, London, 1986 (doi: 10.1016/0168-9525(87)90181-8).

7. K e ne ni G., B e k e le E., I m t i a z M., D a g n e K. Genetic vulnerability of modern crop cultivars: causes, mechanism and remedies. International Journal of Plant Research, 2012, 2(3): 69-79 (doi: 10.5923/j.plant.20120203.05).

8. d e B o e f W.S., B e rg T., H ave rk o rt B. Crop genetic resources. In: Biotechnology; building on farmers' knowledge. J. Bunders, B. Haverkort, W. Hiemstra (eds.). Macmillan, London, Basingstoke, 1996: 103-128.

9. Caballero L., Peca R.J., Martin L.M., Alvarez J.B. Characterization of Mexican Creole wheat landraces in relation to morphological characteristics and HMW glutenin subunit composition. Genet. Resour. Crop Evol., 2010, 57(5): 657-665 (doi: 10.1007/s10722-009-9501-8).

10. B elay G., Tese m m a T., B e chere E., Miti k u D. Natural and human selection for purple-grain tetraploid wheats in the Ethiopian highlands. Genet. Resour. Crop Evol., 1995, 42(4): 387-391 (doi: 10.1007/BF02432143).

11. Tese m ma T., Tsegaye S., B elay G., B e chere E., Mitiku D. Stability of performance of tetraploid wheat landraces in the Ethiopian highland. Euphytica, 1998, 102: 301308 (doi: 10.1023/A:1018361309207).

12. Li S., Sun F., Gu o B., Li u L., Pang Ch. Evaluation of abiotic stress resistance in Hebei winter wheat genetic resources. Wheat Information Service, 1997, 85: 1-6. Available http://jglobal.jst.go.jp/en/public/20090422/200902120034256397. No date.

13. Z o u Z.T., Y a n g W.Y. Development of wheat germplasm research in Sichuan province. Crop Genetic Resources, 1995, 2: 19-20.

14. Jaradat A.A. Phenotypic divergence in the meta-population of the Hourani durum wheat landrace. Journal of Food, Agriculture and Environment, 2006, 4(3-4): 186-191.

15. Vojdani P., Meybodi M. Distribution and genetic diversity of primitive bread wheats in Iran. In: Biodiversity and wheat improvement. A.B. Damania (ed.). John Wiley \& Sons, Chichester, 1993: 409-415.

16. Rodriguez-Quijan o K., Vazquez J.F., Garillo J.M. Variation of high molecular weight glutenin subunits in Spanish landraces of Triticum aestivum ssp. vulgare and ssp. Spelta. Journal of Genetics and Breeding, 1994, 44: 121-126.

17. Lopes M., El-Bas yoni I., Baenziger P., Singh S., Royo C., Ozbek K., Akt a s H., O z e r E., O z d e mi r F., M a n i ckave lu A., B a n T., Vik r a m P. Exploiting genetic diversity from landraces in wheat breeding for adaptation to climate change. J. Exp. Bot., 2015, 66: 3477-3486 (doi: 10.1093/jxb/erv122).

18. K o s h k i n S.S., T s a t s e n k L.B. Nauchnyi zhurnal KubGAU, 2016, 115(01): IDA 1151601051 (in Russ.).

19. M a lk a ndu e v Kh.A., K han i e Yu.D. Tekhnologiya vozdelyvaniya ozimoi pshenitsy [Winter wheat growing]. Nal'chik, 1996 (in Russ.).

20. D o s p e k h o v B.A. Metodika polevogo opyta [Methods of field trials]. Moscow, 1985 (in Russ.).

21. Shapoval O.A., Vakule $\mathrm{nko}$ V.V., Mozharova I.P. Zashchita $i$ karantin rastenii, 2010, 8: 4-7 (in Russ.). 